\title{
GESTATIONAL DIABETES; \\ TO COMPARE THE EFFICACY OF METFORMIN WITH INSULIN IN DIABETES MELLITUS IN TERMS OF FETOMATERNAL OUTCOME
}

1. Professor of Gynae \& Obs. Central Park Medical \& Dental College, Lahore

2. Assistant Professor Gynae \& Obs. Lady Willingdon Hospital, Lahore. 3. Gynaecologist

Lady Willingdon Hospital, Lahore.

4. Consultant Surgeon

LM\&DC Lahore

5. Demonstrator Pathology Fatima Jinnah Medical University for Women Lahore.

6. Vice Chancllor / Prof. of Medicine Fatima Jinnah Medical University for Women Lahore.

7. Professor of Gynae \& Obs Punjab Medical College / Allied Hospital Faisalabad.

8. Professor of Pathology Head of Department Punjab Medical College / Allied Hospital Faisalabad.

Correspondence Address: Dr. Mulazim Hussain Bukhari mulazim.hussain@gmail.com

Article received on:

10/07/2015

Accepted for publication:

17/08/2015

Received after proof reading: $12 / 10 / 2015$

\section{INTRODUCTION}

Gestational diabetes mellitus (GDM), defined as any degree of glucose intolerance with appearance or first detection during pregnancy, affects $2-10 \%$ pregnancies in the United States. ${ }^{1,2}$ Women with gestational diabetes have a $35-60 \%$ risk of developing DM over next $10-20$ years. ${ }^{1}$

Hyperglycemia in pregnancy results in both maternal and fetal complications. Maternal complications consist of hypertension, preeclampsia, increased risk of cesarean delivery, and long term risk of diabetes mellitus. Fetal complications include macrosomia, neonatal hypoglycemia, polycythemia, increased perinatal mortality, congenital malformation, hyperbilirubinemia, respiratory distress syndrome, and hypocalcaemia. Long term effects of macrosomia include increased risk of glucose intolerance, diabetes, and obesity in
Tayyaba Majeed ${ }^{1}$, Rabia Adnan ${ }^{2}$, Irum Mubshar ${ }^{3}$, Hamis Mahmood $^{4}$, Kanwal Saba ${ }^{5}$,

ABSTRACT... Objectives: To compare the efficacy of Metformin with insulin in gestational Methodology: Total 500 pregnant females with GDM were included in the study through nonprobability, consecutive sampling. Patients were divided into 2 equal groups (A: B). Patients group A were given tablet metformin $500 \mathrm{mg}$ by oral route and group B was administrated ( females who had 0 parity, $107(21.4 \%)$ females had parity 1,175 (35\%) females had parity 2, 95 (19\%) females had parity 3,33 (6.6\%) females had parity 4 and $12(2.4 \%)$ females (14.8\%) neonates with metforminand78 (31.2\%) neonates

Key words: $\quad$ Gestational diabetes mellitus, metformin, insulin, preterm birth, neonatal intensive care unit admission, and neonatal hypoglycemia insulin in diabetes mellitus in terms of fetomaternal outcome. Pr Pressiona Med J 2015;22(10):1298-1303. DOI: 10.17957/TPMJ/15.3019

childhood. $^{3}$

The risk factors, for GDM, which should be noted at the first prenatal visit, include obesity, age more than 25 years, past history of gestational diabetes, first-degree relative with diabetes, badobstetrical history, Polycystic ovarian syndrome and certain ethnic groups.

Women having insulin resistance are at risk for developing GDM. This leading to GDM is dueto changes of late pregnancy. In pregnancy, human placental lactogen and tumor-necrosis factor alpha induce changes in the insulin receptor and in post-receptor signaling. Various changes at the cellular level appear to be involved in reducing glucose uptake in skeletal muscle tissue. ${ }^{5}$

The blood sugar levels should be optimized to 
decrease the incidence of fetomaternal complications. The previous study has shown thataggressive management in women with GDMreduced birth weight and macrosomia in infants bornto mothers who were exposed to the intervention compared with women who had received routine care. ${ }^{6}$ Therefore, measures such as dietary modification, exercise, oral hypoglycemic agents, and insulin - are imperative to reduce the complications. $^{7}$

When the above-mentioned measures do not fulfill the criteria to control blood glucose levels in pregnant women, the use of subcutaneous insulin therapy is the standard approach for management of GDM..$^{8,9,10}$ However, insulin use has its own set of problems including multiple daily injections, the risk of hypoglycemia and maternal weight gain. ${ }^{11}$ It needs to be altered depending on the patient's weight and height, glucose levels and activity levels. ${ }_{12}$ The issues relating to patients education and compliance as well as the cost of insulin should be considered. These arguments place oral hypoglycemic therapy into favors for women with GDM.,. ${ }^{13}$ However, it is important to take into account fetomaternal impact of oral hypoglycemic agentsfor the women with GDM. Metformin, which is used for T2D, is a foremost choice. Metformin has been found to have a transplacental transfer rate of $10-16 \%^{14,15}$ this raises possible concerns about risks of fetal anomalies, and undesirable effects for mothers and the newborns after delivery limiting its role

The safety and use of Metformin in pregnancy is under consideration. But the inferences drawn from variety of trials, which are underpowered, ${ }^{16,17,18,19}$ lack the ability to define the relative risks and benefits ofmetformin for GDM.

The rationale of this study was to compare the efficacy of metformin with insulin in terms of fetomaternal outcome in gestational diabetes mellitus. There is variability in the literature that is published internationally. The study results may or may not differ from international data due to poor compliance and genetic variation from patient to patient, in the light of which new suggestions will be made for the liberal use of metformin in population and to minimize the use of parenteral therapy (insulin).

\section{OBJECTIVE}

To compare the outcome of Metformin with insulin in gestational diabetes mellitus.

\section{PATIENTS AND METHODS}

This randomized controlled trial study was carried out on 500 pregnant women with GDM admitted in the antenatal ward of Lady Aitchison Hospital from Jan 2014 to March 2015. Written informed consent was obtained. The women were included in the study through non-probability, consecutive sampling.

Demographic information on all variables included; patient's age, gestational age, body mass index and maternal weight gain during pregnancy were noted. The patients were divided in to two equal groups (A \& B) by randomization. Patients in the group $A$ were given tablet metformin $500 \mathrm{mg}$ by oral route and group $B$ was administrated injection regular insulin by subcutaneous route. Maternal BSL (2 levels i.e. BSF, 1 hour post prandial) were done hospital laboratory until delivery and dose of metformin and insulin was adjusted according to BSL. Fetal monitoring was done by ultrasound in the third trimester for fetal weight evaluation. The women between 20-45 years of age and GDM, gestational more than 20 weeks were included in the study and women who were known diabetic, with history of recent myocardial infarction and twin pregnancy were excluded from the study.

The women were evaluated for outcome measures which were Preterm delivery (It will be considered if birth is at $<37$ gestational weeks on LMP) and Neonatal Hypoglycemia (It was assessed by serum blood glucose level (two or more neonatal glucose values $<2.6 \mathrm{mmol}$ per liter [ $46.8 \mathrm{mg}$ per deciliter] within 24 hour of birth), and all the information was recorded on Performa. The data was analyzed by $t$ and chi square depending on the nature of the variable. A $p$ value of $\leq 0.05$ was considered statistically significant. 


\section{RESULTS}

We conducted this trial with 500 females included in the study with the mean age of $32.14 \pm 6.13$ years. The mean gestational age was $31.07 \pm 3.8$ weeks 24-38weeks). There were 78 (15.6\%) females who had 0 parity, 107 (21.4\%) females had parity 1, 175 (35\%) females had parity 2, 95 (19\%) females had parity 3, $33(6.6 \%)$ females had parity 4 and $12(2.4 \%)$ females had parity 5 .

The mean weight of females before treatment was $70.18 \pm 10.96 \mathrm{~kg}$, which was increased to $73.14 \pm 11.49 \mathrm{~kg}$ after treatment. The overall mean change in weight of females was $2.96 \pm 1.90 \mathrm{~kg}$. There were 114 (22.8\%) females had normal BMI, 213 (42.6\%) were overweight and 173 (34.6\%) were obese.

With metformin, the mean weight of females before treatment was $69.62 \pm 10.93 \mathrm{~kg}$, which was increased to $72.05 \pm 11.73 \mathrm{~kg}$ after treatment, with the mean weight change of $2.44 \pm 1.81$ $\mathrm{kg}$. With insulin, the mean weight of females was $70.75 \pm 10.98 \mathrm{~kg}$, which was increased to $74.24 \pm 11.16 \mathrm{~kg}$, with the mean weight change of $3.49 \pm 1.84 \mathrm{~kg}$. Thus after treatment the difference was significant $(\mathrm{P}<0.05)$.

There were 54 (10.8\%) cases had preterm birth, out of which $12(4.8 \%)$ with metformin and 42 (16.8\%) with insulin (Fig-1, Table-I).

There were 115 (23\%) neonates required NICU admission, out of which 37 (14.8\%) with metformin while 78 (31.2\%) with insulin (Fig-2, Table-II).

There were 87 (17\%) neonates had neonatal hypoglycemia, out of which $23(9.2 \%)$ with metformin while64 $(25.6 \%)$ with insulin (Fig-3, Table-III).

There was significant difference between both groups $(\mathrm{P}<0.05)$.

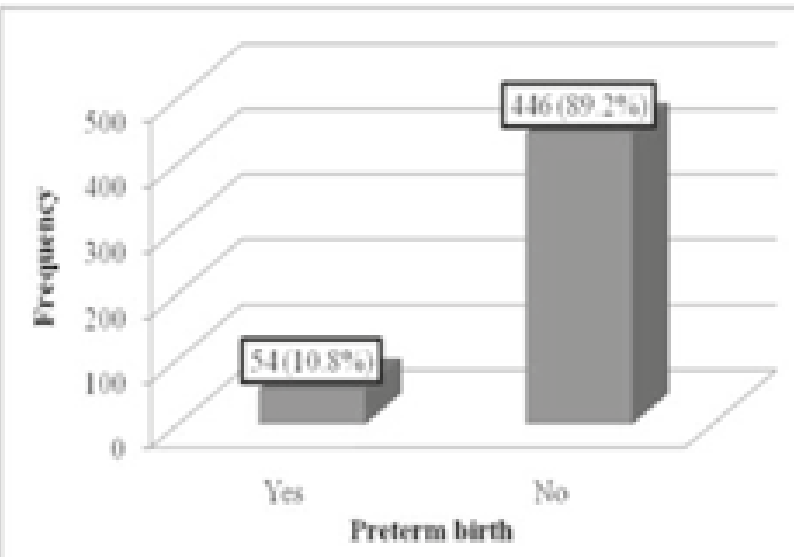

Fig-I. (Distribution of preterm birth)

\begin{tabular}{|c|c|c|c|c|}
\hline & & \multicolumn{2}{|c|}{ Study group } & \multirow{2}{*}{ Total } \\
\hline & & Metformin & Insulin & \\
\hline \multirow{2}{*}{ PTB } & Yes & 12 (4.8\%) & $\begin{array}{c}42 \\
(16.8 \%)\end{array}$ & $\begin{array}{c}54 \\
(10.8 \%)\end{array}$ \\
\hline & No & $\begin{array}{c}238 \\
(95.2 \%)\end{array}$ & $\begin{array}{c}208 \\
(83.2 \%)\end{array}$ & $\begin{array}{c}446 \\
(89.2 \%)\end{array}$ \\
\hline \multicolumn{2}{|c|}{ Total } & $\begin{array}{c}250 \\
(100 \%)\end{array}$ & $\begin{array}{c}250 \\
(100 \%)\end{array}$ & $\begin{array}{c}500 \\
(100 \%)\end{array}$ \\
\hline
\end{tabular}

Table-I. (Comparison of preterm birth in both study groups)

\begin{tabular}{|c|c|c|c|c|}
\hline & \multicolumn{2}{|c|}{ Study group } & \multirow{2}{*}{ Total } \\
\hline & & Metformin & Insulin & \\
\hline \multirow{2}{*}{$\begin{array}{c}\text { NICU } \\
\text { admission }\end{array}$} & Yes & $\begin{array}{c}37 \\
(14.8 \%)\end{array}$ & $\begin{array}{c}78 \\
(31.2 \%)\end{array}$ & $\begin{array}{c}115 \\
(23 \%)\end{array}$ \\
\hline & No & $\begin{array}{c}213 \\
(85.2 \%)\end{array}$ & $\begin{array}{c}172 \\
(68.8 \%)\end{array}$ & 385 (77\%) \\
\hline \multicolumn{2}{|c|}{ Total } & $\begin{array}{c}250 \\
(100 \%)\end{array}$ & $\begin{array}{c}250 \\
(100 \%)\end{array}$ & $\begin{array}{c}500 \\
(100 \%)\end{array}$ \\
\hline
\end{tabular}

Table-II. (Comparison of NICU admission in both study Of neonates)

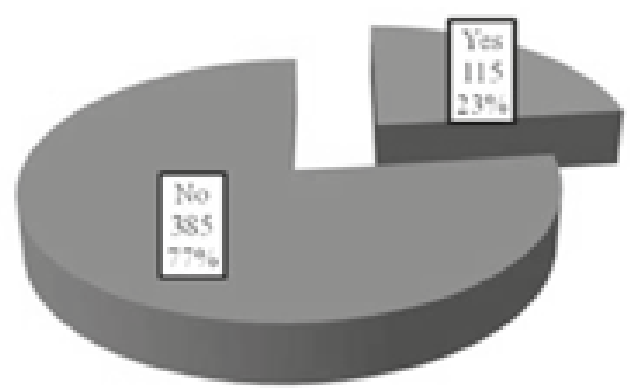

Fig-2. Distribution of NICU admission 


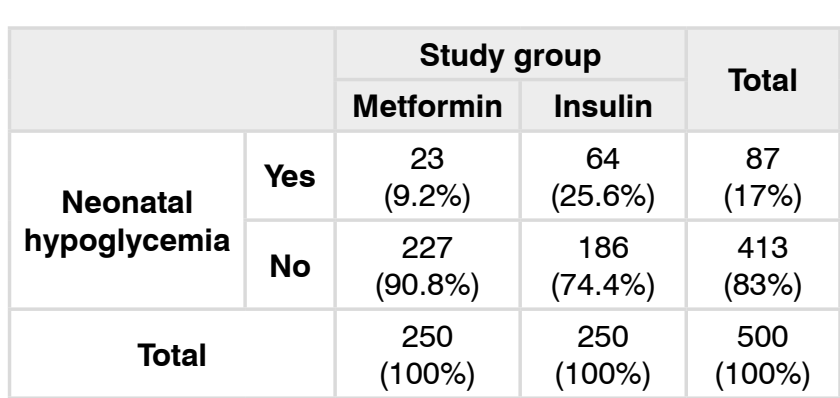

Table-III. (Comparison of neonatal hypoglycemia)

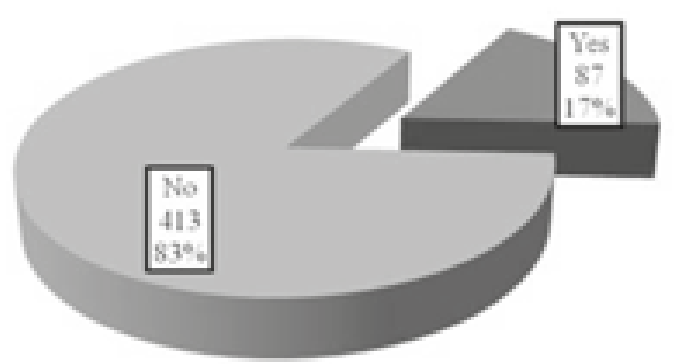

Fig-3. Distribution of Neonatal hypoglycemia in both study groups

\section{DISCUSSION}

In this trial we observed that the mean age of $32.14 \pm 6.13$ years. The mean gestational age was $31.07 \pm 3.8$ weeks $24-38$ weeks). There were 78 (15.6\%) females who had 0 parity, 107 (21.4\%) females had parity 1, 175 (35\%) females had parity 2, 95 (19\%) females had parity 3, 33 (6.6\%) females had parity 4 and 12 (2.4\%) females had parity 5 .

The mean weight of females before treatment was $70.18 \pm 10.96 \mathrm{~kg}$, which was increased to $73.14 \pm 11.49 \mathrm{~kg}$ after treatment. The overall mean change in weight of females was $2.96 \pm 1.90 \mathrm{~kg}$. There were 114 (22.8\%) females had normal BMI, 213 (42.6\%) were overweight and 173 (34.6\%) were obese.

With metformin, the mean weight of females before treatment was $69.62 \pm 10.93 \mathrm{~kg}$, which was increased to $72.05 \pm 11.73 \mathrm{~kg}$ after treatment, with the mean weight change of $2.44 \pm 1.81$ $\mathrm{kg}$. With insulin, the mean weight of females was $70.75 \pm 10.98 \mathrm{~kg}$ which was increased to $74.24 \pm 11.16 \mathrm{~kg}$, with the mean weight change of $3.49 \pm 1.84 \mathrm{~kg}$. Thus after treatment the differ- ence was significant $(P<0.05)$. In a randomized trial by Rowan, mean weight gain was $0.94 \pm 0.3$ with metformin and $2.72+0.4$ with insulin. (20)But another study by Tertti reported that weight gain was $0.4 \pm 2.9 \mathrm{~kg}$ and $2.0 \pm 3.3 \mathrm{~kg}$ with metformin and insulin. ${ }^{16}$

There were 54 (10.8\%) cases had preterm birth, out of which 12 (4.8\%) with metformin and 42 (16.8\%) with insulin. There were 115 (23\%) neonates required NICU admission, out of which 37 (14.8\%) with metformin while78 (31.2\%) with insulin. There were 87 (17\%) neonates had neonatal hypoglycemia, out of which $23(9.2 \%)$ with metformin while64 (25.6\%) with insulin. There was significant difference between both groups $(P<0.05)$.

In the study by Rowan PTB was observed in 0\% cases with metformin and $10 \%$ with insulin, NICU admission in $6 \%$ with metformin and $19 \%$ with insulin, hypoglycemia in $9 \%$ with metformin and 18\% with insulin.(20) The study by Terstti supported our results and reported that with metformin, PTB occurred in $4.4 \%$ cases, NICU admissions in $42.2 \%$ cases and neonatal hypoglycemia in $34.1 \%$ cases. With insulin, PTB occurred in $11.1 \%$ cases, NICU admissions in $62.2 \%$ cases and neonatal hypoglycemia in $57.8 \%$ cases. However, the difference was insignificant $(P>0.05) .{ }^{16}$

When compared with insulin, metformin was associated with less maternal weight gain (pooled mean difference $-1.14 \mathrm{~kg}(95 \% \mathrm{Cl}-2.22$ to -0.06)), lower gestational age at delivery (pooled mean difference -0.16 weeks $(-0.30$ to -0.02$)$ ), and more preterm birth (pooled risk ratio 1.50 (1.04 to 2.16)). A trend was observed towards a lower rate of any neonatal hypoglycaemia (pooled risk ratio $0.78(0.60$ to 1.01$)) \cdot{ }^{21}$

In Tertti study NICU admission was $18 \%$ with metformin and $21 \%$ insulin group, hypoglycemia in $34 \%$ and $57 \%$ with metformin and insulin respectively. ${ }^{16}$ One more study reported contradictory results as reported in our study. It was observed that PTB was $12.1 \%$ with metformin and $7.6 \%$ with insulin and the statistical difference was 
obtained as significant $(P<0.05) .(21)$ In another cohort of women studied by Rowan and Hughes with diabetes, maternal/fetal outcomes were as good in women using metformin as those on insulin alone, even though women in the metformin group were at higher risk of poor outcomes. ${ }^{22}$

In a study conducted by Niromanesh etal the maternal weight gain was reduced in the metformin group $(\mathrm{P}<0.001)$. Two groups were comparable according to neonatal and obstetric complications $(P>0.05) .{ }^{23}$

Mesdaghinia and colleagues conducted a prospective randomized trial in which it was seen that maternal weight gain during pregnancy, preterm labor and hospitalization of infants were higher in in insulin group. But there were no significant statistical differences between the two groups regarding neonatal hypoglycaemia. ${ }^{24}$

In a study conducted by Spaulonci et al it was seen that women using metformin had less weight gain and lower frequency of neonatal hypoglycemia as compared to those using insulin. ${ }^{25} \mathrm{~A}$ recent study has indicated a lesser maternal weight gain but higher incidence of preterm labor with metformin. ${ }^{26}$

\section{CONCLUSION}

It is concluded that metformin is more effective in controlling blood glucose and prevent adverse fetal outcome as compared to insulin and we have proved this through this randomized trial. Thus in future we can recommend metformin instead of insulin for control of GDM in future as we have got local magnitudes which will help us in implementation of metformin and will minimize the use of the use of parenteral therapy i.e. insulin.

Authorship: TM was the principal researcher and collected the data, RA deigned the research Protocol, IM and ZM helped in designing the research protocol, HM gave the computer help, KS did the statistical analysis, SFI and SFZ helped is writing and finalizing the manuscript.

Acknowledgement. We are thankful for the whole staff of Department of Pathology and Obstetrics and gynecology Lady Aitchison Hospital, Lahore on their cooperation during collection and analysis of the data.

Copyright@ 17 Aug, 2015.

\section{REFERENCES}

1. Health UDo, Services H. National Diabetes Information Clearinghouse (NDIC). National Diabetes Statistics. 2011.

2. Metzger BE, Coustan DR. Proceedings of the Fourth International Work-shop-Conference on Gestational Diabetes Mellitus. . Diabetes care. 1998;21(Suppl. 2):B1-B167.

3. Setji TL, Brown AJ, Feinglos MN. Gestational diabetes mellitus. Clinical diabetes. 2005;23(1):17-24.

4. Jovanovic L, Pettitt DJ. Gestational diabetes mellitus. Jama. 2001;286(20):2516-8.

5. Metzger BE, Buchanan TA, Coustan DR, De Leiva A, Dunger DB, Hadden DR, et al. Summary and recommendations of the fifth international workshop-conference on gestational diabetes mellitus. Diabetes care. 2007;30(Supplement 2):S251-S60.

6. Crowther CA, Hiller JE, Moss JR, McPhee AJ, Jeffries WS, et al. (2005) Effect oftreatment of gestational diabetes mellitus on pregnancy outcomes. $\mathrm{N}$ Engl $\mathrm{J}$ Med352: 2477-2486.

7. Evensen AE (2012) Update on gestational diabetes mellitus. Prim Care 39: 83-94.

8. Glueck CJ, Goldenberg N, Streicher P, Wang P (2002) The contentious natureof gestational diabetes: diet, insulin, glyburide and metformin. Expert OpinPharmacother 3: 1557-1568.

9. Association $A D$ (2009) Standards of medical care in diabetes-2009. DiabetesCare 32 Suppl 1: S13-61.

10. Nicholson W, Baptiste-Roberts K (2011) Oral hypoglycaemic agents duringpregnancy: The evidence for effectiveness and safety. Best Pract Res Clin ObstetGynaecol 25: 51-63.

11. Norman RJ, Wang JX, Hague W (2004) Should we continue or stop insulinsensitizing drugs during pregnancy? Curr Opin Obstet Gynecol 16: 245-250.

12. Simmons $D$ (2010) Metformin treatment for Type 2 diabetes in pregnancy? BestPract Res Clin Endocrinol Metab 24: 625-634.

13. Ijas H, Vaarasmaki M, Morin-Papunen L, Keravuo R, 
Ebeling T, et al. (2011)Metformin should be considered in the treatment of gestational diabetes: aprospective randomised study. BJOG 118: 880-885.

14. Nanovskaya TN, Nekhayeva IA, Patrikeeva SL, Hankins GD, Ahmed MS(2006) Transfer of metformin across the dually perfused human placental lobule.Am J Obstet Gynecol 195: 1081-1085.

15. Kovo M, Haroutiunian S, Feldman N, Hoffman A, Glezerman M (2008)Determination of metformin transfer across the human placenta using a duallyperfused ex vivo placental cotyledon model. Eur J Obstet Gynecol Reprod Biol136: 29-33.

16. Tertti K, Ekblad U, Vahlberg T, Ronnemaa T (2008) Comparison of metforminand insulin in the treatment of gestational diabetes: a retrospective, case-controlstudy. Rev Diabet Stud 5: 95-101.

17. Balani J, Hyer SL, Rodin DA, Shehata H (2009) Pregnancy outcomes in womenwith gestational diabetes treated with metformin or insulin: a case-control study.Diabet Med 26: 798-802.

18. Goh JE, Sadler L, Rowan J (2011) Metformin for gestational diabetes in routineclinical practice. Diabet Med 28: 1082-1087.

19. Rai L, Meenakshi D, Kamath A (2009) Metformin-a convenient alternative toinsulin for Indian women with diabetes in pregnancy. Indian J Med Sci 63: 491-497.

20. Rowan JA, Hague WM, Gao W, Battin MR, Moore MP.
Metformin versus Insulin for the treatment of gestational diabetes. N Engl J Med.2008;358(19):2003-15.

21. Balsells M, García-Patterson A, Solà I, Roqué M, Gich I, Corcoy R. Glibenclamide, metformin, and insulin for the treatment of gestational diabetes: a systematic review and meta-analysis. BMJ. 2015;350:h102.

22. Hughes R, Rowan J. Pregnancy in women with Type 2 diabetes: who takes metformin and what is the outcome? Diabetic medicine. 2006;23(3):318-22.

23. Niromanesh S, Alavi A, Sharbaf F, Amjadi N, Moosavi $S$, Akbari $S$. Metformin compared with insulin in the management of gestational diabetes mellitus: A randomized clinical trial. Diabetes Res clin Pract 2012;98:422-429.

24. Mesdaghinia E, Samimi M, Homaei Z, Saberi F, Moosavi S, Yaribakht M. Comparison of newborn outcomes in women with gestational diabetes mellitus treated with metformin of insulin: A randomized blinded trial. Int J Prev Med 2013;4:327-333.

25. Spaulonci C, Bernardes L, Trindade T, Zugaib M, Francisco R. Randomized trial of metformin vs insulin in the management of gestational diabetes. Am J Obst Gynecol 2013;208: Mar 21. pii: S0002- 9378(13)002962. doi: 10.1016/j.ajog.2013.03.022. [Epub ahead of print

26. G Juan, L Qing, F Ling. Metformin vs Insulin in management of gestational diabetese: a meta analysis.PLoS ONE 8(5): e64585. doi:10.1371/journal. pone.0064585

\begin{tabular}{|c|c|c|c|}
\hline \multicolumn{4}{|c|}{ AUTHORSHIP AND CONTRIBUTION DECLARATION } \\
\hline Sr. \# & Author-s Full Name & Contribution to the paper & Author $=s$ Signature \\
\hline 1 & Tayyaba Majeed & $\begin{array}{l}\text { Principal researcher and } \\
\text { collection of data }\end{array}$ & \\
\hline 2 & Rabia Adnan & $\begin{array}{l}\text { Designed the research } \\
\text { Protocol }\end{array}$ & \\
\hline 3 & Irum Majeed & $\begin{array}{l}\text { Helped in designing the } \\
\text { research protocol }\end{array}$ & \\
\hline 4 & Hamis Mahmood & Give the computer help & \\
\hline 5 & Kanwal Saba & Did the statistical analysis & \\
\hline 6 & Sardar Fakhar Imam & $\begin{array}{l}\text { Helped is weiting and } \\
\text { finalizing the manuscript }\end{array}$ & \\
\hline 7 & Muhammad Al-Fareed Zafar & $\begin{array}{l}\text { Helped is weiting and } \\
\text { finalizing the manuscript }\end{array}$ & \\
\hline 8 & Mulazim Hussain Bukhari & Supervised the research & \\
\hline
\end{tabular}

